\title{
Forest Tenure and Sustainable Forest Management
}

\author{
Jacek P. Siry'1, Kathleen McGinley², Frederick W. Cubbage³, Pete Bettinger ${ }^{1}$ \\ ${ }^{1}$ Warnell School of Forestry and Natural Resources, University of Georgia, Athens, Georgia, USA \\ ${ }^{2}$ USDA Forest Service, International Institute of Tropical Forestry, Río Piedras, Puerto Rico \\ ${ }^{3}$ Department of Forestry and Environmental Sciences, North Carolina State University, Raleigh, North Carolina, \\ USA \\ Email: jsiry@uga.edu, kmcginley@fs.fed.us, fred cubbage@ncsu.edu, pbettinger@warnell.uga.edu
}

Received 1 May 2015; accepted 13 June 2015; published 18 June 2015

Copyright (C) 2015 by authors and Scientific Research Publishing Inc.

This work is licensed under the Creative Commons Attribution International License (CC BY).

http://creativecommons.org/licenses/by/4.0/

(c) (i) Open Access

\begin{abstract}
We reviewed the principles and key literature related to forest tenure and sustainable forest management, and then examined the status of sustainable forestry and land ownership at the aggregate national level for major forested countries. The institutional design principles suggested by Ostrom are well accepted for applications to public, communal, and private lands. The analyses of countries as a whole suggest that problems of forest land loss and sustainable forest management are related to the amount of public lands owned, as well as the difference between developed and developing countries. Developed countries have largely achieved a stable level of land use and resource extraction after centuries of exploitation of forests and natural resources. Many developed countries do have greater amounts of private forest land than developing countries, which have occurred as the countries transfer lands to private owners in the course of development. Public lands and management approaches require diligence, but can be developed to meet the design criteria suggested by tenure rights theorists. Private or communal ownership is often considered superior, but also must meet the criteria suggested above in order to foster sustainable forest management in poor countries.
\end{abstract}

\section{Keywords}

Forest Tenure, Property Rights, Sustainable Forest Management

\section{Introduction}

Global forestry problems such as deforestation, degradation, and biodiversity loss have persisted for decades.

How to cite this paper: Siry, J. P., McGinley, K., Cubbage, F. W., \& Bettinger, P. (2015). Forest Tenure and Sustainable Forest Management. Open Journal of Forestry, 5, 526-545.

http://dx.doi.org/10.4236/ojf.2015.55046 
More recently, new challenges have been identified, such as atmospheric carbon capture and storage in forests and the role they fulfill in global climate change mitigation efforts (Canadell \& Raupach, 2008). Various public, private, and nongovernmental efforts have been developed and implemented to address these problems, but their success has been modest to date. Many new international, regional, local, and private forest institutions have been developed in the last decade in order to improve forest conditions and retention (Cashore, Gallowey, Cubbage, Humphreys, Katila, Levin et al., 2010). Tenure arrangements and reform have been identified as crucial components among the many new policies and institutions introduced for improving sustainable forest management.

Unclear and insecure property and resource rights have been identified as significant factors in forest decline and degradation. When rights to forest land and resources are contested, overlap, or are not enforced, forest users and rights holders have few incentives, and may even lack the legal status, to invest in management and protection, which ultimately undermines efforts to ensure forest sustainability (White \& Martin, 2002). Furthermore, while the vast majority of the world's forest land historically has been under public ownership, forests have been degraded and lost at alarming rates, although this rate of deforestation has decelerated somewhat in the last five years (FAO, 2010). This awareness of the important link between forest tenure and forest retention, protection, and management has triggered debate and research about the efficiency, equity, and sustainability of public and private forest management.

In this review article, we examine the role of tenure in leading to sustainable forest management. To do so, we review the literature on forest tenure and empirical studies about its impacts on management, examine selected data from the recent Food and Agriculture Organization of the United Nations (FAO) Global Forest Resource Assessment (FAO, 2010), and complement these sources with data about governance and corruption. Based on this theory, literature review, and the relevant data by country, we provide a synthesis of the impacts of land tenure on sustainable forest management of global forests.

\section{Theory and Literature}

\subsection{Tenure Rights}

The term "tenure" dates back to English feudalism and has come to represent the rights and obligations of a resource holder (Bruce, 1998). According to the FAO (2011), forest tenure is a broad concept encompassing ownership, tenancy, rights and other arrangements to manage and use forest land and resources. Forest tenure determines "who can use what resource, for how long, and under what conditions" (FAO, 2002). Bromley (1991) considers property as a stream of benefits and, consequently, a property right as a claim to a particular stream of benefits. In order for property rights to be meaningful, the state agrees to protect them, making it a duty of others (who do not hold a property right) not to interfere with the benefit stream. In this context, property is not considered a physical object but rather a social construct, encompassing benefit streams, rights (holders), and duties (others).

Tenure is important because it affects the incentive framework faced by forest owners, users, and managers. It has an important economic role in determining who benefits and who loses in competition for (scarce) forest resources (Alchian \& Demsetz, 1973). It provides a foundation for the survival of forest-dependent indigenous, tribal, and local communities (RRI \& ITTO, 2009). In general, clear and secure tenure is a prerequisite for capital investments in forestry, and influences local decisions related to forest protection and forest destruction.

Tenure may be formal or informal, whereby formal tenure arrangements are legally recognized by the state, while informal tenure arrangements have no statutory recognition (FAO, 2011). Customary and traditional tenure arrangements refer to locally recognized rules and uses that are often informal, though they are increasingly being formally recognized and typically encompass locally recognized rules typified by customary or traditional tenure arrangements. When customary tenure is not formally recognized, it may lead to conflicts between traditional and statutory users. In many cases, informal customary and formal statutory tenure arrangements co-exist, though seldom harmoniously. Some suggest that where customary tenure remains informal, tenure reform should include its recognition (FAO, 2011; FAO, 2010; Larson, Cronkleton, Barry, \& Pacheco, 2008; Lynch, 2011a; Lynch, 2011b; Pacheco, Barry, Cronkleton, \& Larson, 2008).

Whether formal or informal, tenure security is fundamental to the effectiveness of existing tenure arrangements and prospective tenure reforms (Godoy, Jacobson, De Castro, Aliaga, Romero, \& Davis, 1998; Sunderlin, Hatchers, \& Liddle, 2008; FAO, 2011). Secure tenure is often characterized by clearly defined rights that cannot 
be taken away without due process, and which are enforceable, exclusive, durable (permanent), and legally recognized (FAO, 2011). Also, it typically means possessing a clear legal title to forest land or resources. As a result, in many ways, statutory tenure is considered more secure than informal tenure, though enforceability may be the most important characteristic of tenure security.

Tenure is often mistakenly equated with ownership. However, ownership, which allocates strong rights to the holder of land, usually including exclusive and permanent rights, along with the right to sell or lease the land and its resources, represents only one type of tenure. To better understand and analyze forest tenure arrangements, tenure can be considered a bundle of property rights that represent an "enforceable authorization to undertake particular actions in a specific domain” (Ostrom \& Hess, 2007). A forest user may hold some or all of these rights, but any rights depend on the formal laws and informal customs that have developed regarding resource use.

As outlined by Schlager \& Ostrom (1992), property rights define the relationship between the right(s) holder and all others, which can be depicted as shown in Table 1. The levels of those rights distinguish the characteristic of the ownership. Aspects of these include the right to enter a specified property-access; the right to harvest specific products-withdrawal; the right to transform or regulate the resource-management; the right to decide who can access, harvest, or manage the resource-exclusion; and the right to lease or sell any of the other four rights-alienation (Schlager \& Ostrom, 1992). The level of control exercised by the rights holder depends on whether they own the land, are proprietors, claimants, authorized users, or simply entrants or viewers (Schlager \& Ostrom, 1992; Ostrom \& Hess, 2007).

Property rights may be held by individuals or collectively by communities or other groups and may be assigned to the holder(s) separately or cumulatively. Property rights can also be viewed on an increasing scale, with the single right to access being given to an entrant or viewer up to a complete set of rights bestowed on full ownership (Ostrom, 2000). The rights that the holder holds are important for determining their incentives to protect and sustainably manage the resource (Alchian \& Demsetz, 1973).

Forests share characteristics with both private goods (which are rival and excludable) and public goods (which are nonrival and nonexludable). Ostrom (2005) classified forests as common-pool resources which share high subtractability of use with private goods and high difficulty of exclusion with public goods. Subtractability means that benefits consumed by somebody reduce benefits available to others, which is true for most (but not all) forest outputs. High difficulty of exclusion implies that the cost of exclusion of nonauthorized beneficiaries is also high because of the extensive nature of forest resources and problems in exercising control over them. These attributes have important implications for policy approaches and economic activities as their status may determine winners and losers. Some of these attributes are more conducive to private (individual) ownership, some to government ownership, and some to communal (group) ownership.

Common-pool resources can be and are owned by government, communities, individuals and corporations, and even by no one when they are nonexludable and access and use are open to anyone. Ostrom (1990; 2005) and colleagues have long studied common pool resources to identify core underlying lessons or "design principles" that characterize enduring governance regimes as compared to the cases of governance failure. These design principles or "best practices" have been summarized by Cox, Arnold, \& Villamayor (2010, as quoted in Ostrom, 2010):

1A) User Boundaries: Clear and locally understood boundaries between legitimate users and nonusers are present.

Table 1. Bundels of rights associated with land users.

\begin{tabular}{cccccc}
\hline Level of rights/title & Owner & Proprietor & Claimant & Authorized user & Entrant/viewer \\
\hline Access & $\mathrm{X}$ & $\mathrm{X}$ & $\mathrm{X}$ & $\mathrm{X}$ & $\mathrm{X}$ \\
Withdrawal & $\mathrm{X}$ & $\mathrm{X}$ & $\mathrm{X}$ & $\mathrm{X}$ & \\
Management & $\mathrm{X}$ & $\mathrm{X}$ & & \\
Exclusion & $\mathrm{X}$ & $\mathrm{X}$ & & \\
Alienation & $\mathrm{X}$ & & & \\
\hline
\end{tabular}

Adapted from Schlager and Ostrom (1992), Ostrom \& Hess (2007). 
1B) Resource Boundaries: Clear boundaries that separate a specific common-pool resource from a larger social-ecological system are present.

2A) Congruence with Local Conditions: Appropriation and provision rules are congruent with local social and environmental conditions.

2B) Appropriation and Provision: Appropriation rules are congruent with provision rules; the distribution of costs is proportional to the distribution of benefits.

3) Collective Choice Arrangements: Most individuals affected by a resource regime are authorized to participate in making and modifying its rules.

4A) Monitoring Users: Individuals who are accountable to or are the users monitor the appropriation and provision levels of the users.

4B) Monitoring the Resource: Individuals who are accountable to or are the users monitor the condition of the resource.

5) Graduated Sanctions: Sanctions for rule violations start very low but become stronger if a user repeatedly violates a rule.

6) Conflict Resolution Mechanisms: Rapid, low cost, local arenas exist for resolving conflicts among users or with officials.

7) Minimal Recognition of Rights: The rights of local users to make their own rules are recognized by the government.

8) Nested Enterprises: When a common-pool resource is closely connected to a larger social-ecological system, governance activities are organized in multiple nested layers.

Though Ostrom (2010) acknowledges there are no specific rules or practices that are always associated with successful cases across all forestry, fishing, grazing, and other uses, these principles help determine whether various public or private forest institutions can protect and manage common-pool forests sustainably. In particular, common-pool resource attributes that may be conducive to communal management and ownership include easier and less costly exclusion of nonauthorized users (compared with individual ownership), sharing risk and cost, and nesting within a series of government units (for formally recognized systems) offering benefits of shared organizational skills and knowledge (Ostrom, 2000). In other words, these are the attributes that make the overall benefits of collective action exceed the overall benefits of individual or state action.

\subsection{Forest Tenure Reforms}

Various proposals have been made to reform forest tenure, which may help clarify the rights of forest resource users, protect the resource, and enhance sustainable forest management. A prevalent set of tenure reforms are related to decentralization and devolution of forest management. Decentralization may occur within the same ownership, for example, by transferring decision-making powers from the central government to its local administrative units. Devolution represents more dramatic changes when transfer of decision-making powers to other owners such as communities or individuals.

Other tenure reforms have focused on privatization of public lands. This has occurred in developed countries, such as New Zealand, formerly communist Eastern Europe, and the Southern Hemisphere, such as South America. Other countries such as Vietnam and China have retained lands in public ownership, but have transferred all tenure rights to new resource users for up to 50 years. Forest concessions, such as in the Amazon (Bauch, Sills, Rodriguez, McGinley, \& Cubbage, 2009), forest leases, and other intermediate policy tools have been used to assign rights to public property to private companies or individuals.

Similarly, private forest owners may assign rights to develop forest plantations on their lands to timber companies, or become contractors for timber companies and receive annual payments. And historically the rights of surface ownership and use have often been separated from the rights of subsurface ownership and use, such as for mining, oil and gas, and even water use. All of these arrangements assign part of the bundle of rights to land to different resource users.

In addition, land tenure is only one part of a complex and diverse system that influences forest use and management and cannot be considered in isolation from its other components, the most important being regulatory frameworks and governance (FAO, 2011). This is because forest use is driven usually by broader, national development policies along with particular processes for making decisions to which forest tenure reforms must conform. Other factors that bear at least a mention are the level of economic development, including infrastruc- 
ture, markets and industries, and forest and industrial technologies; forest resource structure and condition; demographic conditions and pressures; and even cultural factors. The level of country economic development influences the country's need with respect to its forests while also determining what resources and approaches are available to manage forest resources.

Regulatory frameworks comprise legislation, policies, executive rules, and operational guidelines (FAO, 2011). It is argued that regulatory frameworks should be enabling as well as enforcing. While most countries have forest policies based on principles of sustainability, alone they rarely produce progress in achieving sustainable forest management, which may be due to their poor design or execution or both. Cross-sectoral policies are equally important, since they may inhibit or promote the development of markets, sustainable forest product industries, and trade (Geist \& Lambin, 2002).

\subsection{Selected Literature}

Much of the literature on forest tenure and its impacts explicitly or implicitly touches on Ostrom's design principles for the long-term survival of resource institutions (Ostrom, 2010; Cox, Arnold, \& Villamayor, 2010). For example, Cox, Arnold, \& Villamayor (2010) found that a large majority (2/3 of more than 100 reviewed cases) of robust resource systems are characterized by most of these design principles. Furthermore, Tucker (2010) indicates that a subset of Ostrom's design principles: secure rights, institutions that fit local context, and monitoring and rule enforcement, must be present for most forest governance regimes to work. Though not sufficient on their own, this subset of principles is noteworthy because they have been found to be associated with sustainable forest governance in public, private, and common-property regimes, as well as across diverse forest types, cultural groups, national contexts, and political economic situations. Ultimately, most common-property theorists argue that institutional arrangements, rather than specific forms of property rights (public, private, common) are most important for sustainable forest use.

Regarding community forestry (whether on state or communal lands), research provides strong evidence that this type of tenure can have positive outcomes, including reduced rates of deforestation, maintenance or increase in forest cover, and maintenance of forest vegetation density, as well as improved livelihood conditions, particularly where tenure and boundaries are clear and where there is local participation in rule making, monitoring, and enforcement. However, it should be noted that while numerous papers argue that community forestry can be "successful” or "sustainable" or "effective”, few clearly define what these terms mean nor measure "success" or "effectiveness" in relation to policy or resource management goals or objectives.

Also noted by Andersson \& Gibson (2007), outcome measures used to assess institutional arrangements have often not taken into account policy goals. Likewise, it hardly makes sense to declare a community-managed forest as a failure when basal area is reduced, if a policy objective is to generate revenue through commercial logging. Though rarely the case in practice, assessments of forest conditions under different tenure and management regimes should better link the assessment outcome measures to the actual policy or management goals (for exceptions see (Coleman, 2009; Coleman \& Steed, 2009).

In addition, it is difficult to find studies of forest tenure outcomes that account for hunting, foraging, and other human pressures that may contribute to biodiversity impacts beyond those associated with forest habitat loss or degradation. So, even where community forestry and other tenure arrangements protect forest area or inhibit deforestation and fire, little is known about the additional impacts that human presence has on important aspects of forest biodiversity. For example, Terborgh \& Peres (2002) assert that "much research confirms that humans and wild nature are incompatible except where humans practice a low impact pre-modern lifestyle at densities of no more than a few individuals per square kilometer.”

When sufficient resources are made available for monitoring and enforcement, parks and other public governance of forests can be effective at protecting biodiversity and attaining other conservation goals, though these regimes certainly are not fail-proof and have their fair share of challenges (Dietz, Ostrom, \& Stern, 2003). Governments often lack the resources or political will to invest in protecting forests, or make ineffective management choices (Stroup, 1998; Stroup \& Baden 1973). Alternatively, governments may intentionally use forests to generate income through concessions, timber sales, or economic development initiatives that can also lead to conversion, resource degradation, and undervaluation of forest resources.

Studies of the "commons" also demonstrate that the social and economic benefits associated with local control over forest management have been mixed and unequally distributed, often influenced by the degree to which 
decentralization or devolution have occurred and what has been decentralized or devolved. All too often, while decentralization or devolution may be absolute "on paper”, complete control of forest resources is rarely transferred to local authorities or communities (Charnley \& Poe, 2007; Larson, Cronkleton, Barry, \& Pacheco, 2008). Moreover, even where decentralization or devolution are advancing, they do not unequivocally lead to forest sustainability, since local people and local governments may benefit more from intensive forest uses or from deforestation (Tacconi, 2007).

The long term security associated with private forest land may be an incentive for long term investment and management, and in turn is a theoretical advantage for forest sustainability (Stroup, 1998). However, since sustainable forest management tends to be less profitable than alternative land uses in many places, it is susceptible to market influences that can result in forest conversion, ultimately impacting ecosystem and landscape functions. While privatization of forest land can result in positive economic, ecological, and social outcomes, the parcelization associated with privatization often results in diverse, uncoordinated activities, some land use change, and, ultimately, forest fragmentation (Karsenty, Drigo, Piketty, \& Singer, 2008; Tucker, 2007).

For private forest land, the supposed advantage to forest sustainability comes from the long term security it provides the land holder, which, in turn, may be an incentive for long term investment and management (Stroup, 1998). However, since sustainable forest management is less profitable than alternative land uses in many places, it is all too often susceptible to market influences that result in forest conversion, ultimately impacting ecosystem and landscape functions. Though there are certainly some examples of positive outcomes from private forestry in terms of ecological, economic and social sustainability, the potential parcelization associated with privatization often results in diverse, uncoordinated activities, some land use change, and, ultimately, forest fragmentation (Karsenty, Drigo, Piketty, \& Singer, 2008; Tucker, 2010). While this may represent a management challenge, landscape level environmental outcomes do not have to be necessarily negative.

Intermediate policy solutions for tenure problems include long term forest concessions granted to industry, communities, or indigenous groups, for example. In an in-depth examination of industrial forest concessions, Karsenty, Drigo, Piketty, \& Singer (2008) establish that in countries where large tracts of forest are state-owned, concessions can deliver services of public and collective interest through an association of private investment and public regulation. In theory, "the conditional use of the land stipulated by contract between the government and the [forest] concessionaire gives, in principle, additional security to a government willing to prevent forest conversion and enforce SFM, but with a limited capacity to fully enforce existing laws” (Karsenty, Drigo, Piketty, \& Singer, 2008). The authors argue that the success of an industrial concession model depends first, on the fact that forest functions and services are managed and maintained as public goods, and second, on effective monitoring and enforcement, especially where there may be asymmetrical information between the principal (i.e., regulating authorities) and the agent (i.e., concessionaires). Industrial forest concessions are not appropriate everywhere, particularly when other tenure approaches may lead to improved local livelihoods. However, in extensive forested areas with low population density, insufficient public presence and infrastructure, and limited small-scale or community alternatives, industrial forest concessions have a "raison d'être". Ultimately, when forests are "characterized by unclear land rights and subsequent risks of forest conversion to create de facto individual land rights, a concession regime can fill the vacuum created by a confusing land tenure situation in order to contribute to forest protection against conversion” (Karsenty, Drigo, Piketty, \& Singer, 2008).

In sum, much of the literature on forest tenure indicates that whatever form a forest management institution takes (public, private, communal), to be effective it must have clear and legitimate rules regarding who has access and use rights to forests; monitoring and enforcement mechanisms supported by sufficient resources; and sanctions for rule breaking. It is also evident that when local forest users play a role in developing rules or consider the rules legitimate, they are much more likely to follow them and to participate in monitoring and enforcement. Furthermore, when institutions fit the local context and are adaptive to social, economic, and environmental change processes, they are more robust and enduring. As many have noted, there are no panaceas that ensure sustainable forest governance, but rather context seems to matter most in designing robust and enduring policies given the complex socioecological systems that forests represent.

\section{Aggregate Empirical Evidence}

In order to empirically assess the effects of forest tenure on sustainable forest management, we analyzed aggregate FAO data for selected countries in the world, supplemented by the results of numerous country and case 
studies. These analyses compared the bundles of property rights that forest holders have and how they influence the achievement of various sustainability goals. First, we analyzed basic forest ownership data for major world regions and their most forested countries (Table 2). Second, we examined data about the status, management, and environmental conditions of forest resources (Table 3) and their correlations with forest tenure and sustainable forest management. Last, we examined the influence of population, economic variables, property rights scores, and freedom from corruption on sustainable forest management (Table 4). We also estimated Pearson correlation statistics among many of the key variables.

\subsection{Global Forest Ownership}

The Food and Agriculture Organization of the United Nations (FAO) is the primary source of information regarding global forest area and ownership. FAO reports ownership data for public, private, and other ownership groups. Such a broad categorization necessarily groups together various types of tenure arrangements.

According to FAO (2010) 80\% of the world's forests are actually publicly owned (Table 2). Public ownership represents forests owned by federal, state, and public administration units as well as publicly owned institutions and corporations. Although the amount varies from one country to the next, only $18 \%$ of the world forests are privately owned. Private ownership is a diverse category which comprises individuals, families, communities, business entities (private firms, corporations, and investment funds), private religious and educational entities, non-governmental organizations (NGOs), nature conservation societies and other private entities. Only $2 \%$ of the world's forests are classified in the other ownership category, including unknown and disputed ownership. This category includes, for example, forest land in Estonia where ownership still needs to be determined or Mexico's comunidades agrarias or ejidos which have collective access rights to portions of land (Bocco, Rosete, Bettinger, \& Velázquez, 2001).

Public forest ownership is prevalent in all regions of the world, with Africa, Asia, and Europe having the highest proportion. Public ownership dominates in many countries with large forest resources, such as the Russian Federation, Brazil, Canada, Democratic Republic of Congo or Indonesia. Public forests can be and are managed by the state and its agencies, communities, individuals and the private sector (Table 2). Worldwide, states and their agencies are responsible for the management of about $80 \%$ of publicly owned forests (FAO, 2010). Private institutions and corporations manage about $10 \%$ of these forests, followed by local, indigenous and tribal communities which are responsible for another 7\%. Private entities are particularly important in Australia, Indonesia, the Congo basin, managing 58\%, 30\%, and 14\% of publicly owned forests, respectively. Private corporations may be important in other regions as well. Another form of management on public lands, community management, is rather common in India, the Philippines, northern Brazil, Mexico, and Papua New Guinea.

While public ownership may dominate the land ownership spectrum, ownership patterns can vary substantially across the regions. For example, while all forests in the Russian Federation are publicly owned, public ownership in nearby Western Europe represents only a portion of the whole forest estate. Excluding the Russian Federation, public forest ownership accounts for only $46 \%$ of European forest area. France, Norway, and Sweden, for example, have more than $70 \%$ of their forests privately owned. Other countries, such as Germany (53\% public forests) or Switzerland (68\% public forests), have extensive public forest systems.

North and Central America (particularly the United States, Nicaragua, Costa Rica), South America (Columbia, Paraguay, Chile), and Oceania (New Zealand, Papua New Guinea) have a higher proportion of private forests than other world regions. While information about the specific composition or private forest ownership is limited, FAO (2010) indicates that for the reporting countries, most forests were owned by individuals (61\%), followed by institutions and corporations (21\%), and local communities and indigenous people (18\%). Corporate ownership was significant in North America, Europe (excluding the Russian Federation), and parts of Asia. Local communities and indigenous people are significant forest owners in Central America (Guatemala, Honduras, and Mexico).

Although communities are involved in the management of public land, they also own and manage private land, thus they are a sub-category of private ownership according to FAO's definition above, have a very long history, and are widespread around the world. Wherever there are people living in or near forests they must have developed some arrangements regarding access and use of these resources. Sunderlin, Hutchers, \& Liddle (2008) estimated that in 30 of the most forested countries the area of private community forests accounted for $9 \%$ of the total forest area and the area of forests designated for use by communities accounted by another $2 \%$. These 
Table 2. Forest ownership (\%) and management rights (\%).

\begin{tabular}{|c|c|c|c|c|c|c|c|c|c|c|c|}
\hline \multirow[b]{2}{*}{$\begin{array}{l}\text { Country/ } \\
\text { area }\end{array}$} & \multicolumn{3}{|c|}{ Ownership pattern } & \multicolumn{3}{|c|}{ Private ownership } & \multicolumn{5}{|c|}{ Holder of management rights of public forests } \\
\hline & $\begin{array}{c}\text { Public } \\
\text { ownership }\end{array}$ & $\begin{array}{c}\text { Private } \\
\text { ownership }\end{array}$ & Other & Individuals & $\begin{array}{c}\text { Business } \\
\text { entities } \\
\text { and } \\
\text { institutions }\end{array}$ & $\begin{array}{c}\text { Local, } \\
\text { indigenous } \\
\text { and tribal } \\
\text { communities }\end{array}$ & $\begin{array}{c}\text { Public } \\
\text { administration }\end{array}$ & Individuals & $\begin{array}{c}\text { Business } \\
\text { entities } \\
\text { and } \\
\text { Institutions }\end{array}$ & Communities & Other \\
\hline Angola & 100 & 0 & 0 & - & - & - & 100 & 0 & 0 & 0 & 0 \\
\hline Congo DR & 100 & 0 & 0 & - & - & - & 90 & 0 & 10 & 0 & 0 \\
\hline Mozambique & 100 & n.s. & 0 & - & - & - & 98 & 0 & 2 & 0 & 0 \\
\hline Tanzania & 100 & n.s. & 0 & - & - & - & 37 & 0 & 0 & 0 & 63 \\
\hline Zambia & 100 & 0 & 0 & - & - & - & 24 & 7 & 3 & 61 & 4 \\
\hline Africa & 94 & 4 & 1 & - & - & - & - & - & - & - & - \\
\hline China & 68 & 32 & 0 & - & - & - & 100 & 0 & 0 & 0 & 0 \\
\hline India & 86 & 14 & 0 & - & - & - & 63 & 0 & 0 & 37 & 0 \\
\hline Indonesia & 91 & 9 & 0 & - & - & - & 43 & n.s. & 57 & n.s. & 0 \\
\hline Myanmar & 100 & n.s. & 0 & 0 & 0 & 100 & - & - & - & - & - \\
\hline Asia & 82 & 18 & 0 & - & - & - & - & - & - & - & - \\
\hline Finland & 32 & 68 & 0 & 84 & 16 & 0 & 100 & 0 & 0 & 0 & 0 \\
\hline France & 26 & 74 & 0 & 84 & 16 & 0 & 38 & 0 & 0 & 62 & 0 \\
\hline Russia & 100 & 0 & 0 & - & - & - & 83 & 0 & 17 & 0 & 0 \\
\hline Spain & 29 & 66 & 5 & 97 & 0 & 3 & 100 & 0 & 0 & 0 & 0 \\
\hline Sweden & 24 & 76 & 0 & 63 & 29 & 8 & 100 & 0 & 0 & 0 & 0 \\
\hline Europe & 90 & 10 & $\mathbf{0}$ & - & - & - & - & - & - & - & - \\
\hline Guatemala & 42 & 52 & 5 & - & - & - & 100 & 0 & 0 & 0 & 0 \\
\hline Canada & 92 & 8 & n.s. & 84 & 16 & 0 & 100 & 0 & 0 & 0 & 0 \\
\hline Mexico & 4 & 26 & 70 & - & - & - & - & - & - & - & - \\
\hline $\begin{array}{l}\text { United States } \\
\text { of America }\end{array}$ & 43 & 57 & 0 & 69 & 31 & 0 & 100 & 0 & 0 & 0 & 0 \\
\hline $\begin{array}{c}\text { North \& } \\
\text { Central } \\
\text { America }\end{array}$ & 62 & 32 & 6 & - & - & - & - & - & - & - & - \\
\hline Australia & 74 & 24 & 1 & - & - & - & 38 & 0 & 62 & 0 & 0 \\
\hline New Zealand & 64 & 36 & 0 & - & 16 & - & 100 & 0 & 0 & 0 & 0 \\
\hline $\begin{array}{l}\text { Papua New } \\
\text { Guinea }\end{array}$ & 3 & 97 & 0 & 0 & 0 & 100 & 96 & 0 & 4 & 0 & 0 \\
\hline Oceania & 62 & 37 & 1 & - & - & - & - & - & - & - & - \\
\hline Bolivia & 100 & n.s. & 0 & - & - & - & 85 & 2 & 10 & 1 & 1 \\
\hline Brazil & 81 & 19 & 0 & - & - & - & 63 & 0 & 0 & 37 & 0 \\
\hline Colombia & 22 & 67 & 11 & 0 & 0 & 100 & 100 & 0 & 0 & 0 & 0 \\
\hline \multicolumn{12}{|l|}{ Paraguay } \\
\hline Peru & 62 & 18 & 20 & - & - & - & 40 & 0 & 0 & 0 & 60 \\
\hline Venezuela & 100 & 0 & 0 & - & - & - & 96 & 0 & 4 & 0 & 0 \\
\hline $\begin{array}{c}\text { South } \\
\text { America }\end{array}$ & 75 & 21 & 4 & - & - & - & - & - & - & - & - \\
\hline World & 80 & 18 & 2 & - & - & - & - & - & - & - & - \\
\hline
\end{tabular}

Sources: (FAO, 2010), Note: -, data not available; n.s., not significant. 
Table 3. Forest area and management in selected countries and regions.

\begin{tabular}{|c|c|c|c|c|c|c|c|c|c|}
\hline Country/region & $\begin{array}{c}\text { Total } \\
\text { forest area } \\
\text { (1000 ha) }\end{array}$ & $\begin{array}{l}\text { Forest } \\
\text { cover } \\
\text { (\% of } \\
\text { land } \\
\text { area) }\end{array}$ & $\begin{array}{c}\text { Forest area } \\
\text { change } \\
1990-2010 \\
(\%)\end{array}$ & $\begin{array}{l}\text { Planted } \\
\text { forest area } \\
\text { (1000 ha) }\end{array}$ & $\begin{array}{c}\text { Industrial } \\
\text { roundwood } \\
\text { harvest } \\
\left(1000 \mathrm{~m}^{3} \text { ob }\right)\end{array}$ & $\begin{array}{l}\text { Wood fuel } \\
\text { harvest } \\
\left(1000 \mathbf{~ m}^{3}\right. \\
\text { ob) }\end{array}$ & $\begin{array}{c}\text { Permanent } \\
\text { forest estate } \\
\text { (\% of } \\
\text { forest area) }\end{array}$ & $\begin{array}{c}\text { Forest in } \\
\text { protected } \\
\text { area } \\
(\% \text { of } \\
\text { forest } \\
\text { area) }\end{array}$ & $\begin{array}{l}\text { Forest with } \\
\text { mgnt plan (\% } \\
\text { of forest area) }\end{array}$ \\
\hline Angola & 58,480 & 47 & -4.1 & 128 & 1260 & 4108 & 100 & & 3 \\
\hline Congo DR & 154,135 & 68 & -3.9 & 59 & 205 & 81,580 & - & & 11 \\
\hline Mozambique & 39,022 & 50 & -10.0 & 62 & 1507 & 19,233 & - & & 11 \\
\hline Tanzania & 33,428 & 38 & -19.4 & 240 & 2661 & 24,970 & 39 & & 85 \\
\hline Zambia & 49,468 & 67 & -6.3 & 62 & 1179 & 10,002 & 7 & & 23 \\
\hline Africa & 674,419 & 23 & -10.0 & 12,239 & 72,000 & 616,000 & 53 & & 17 \\
\hline China & 206,861 & 22 & 31.6 & 77,157 & 63,882 & 63,676 & 100 & & 62 \\
\hline Japan & 24,979 & 69 & 0.1 & 10,326 & 17,803 & 160 & 53 & & 100 \\
\hline India & 68,434 & 23 & 7.0 & 9846 & 45,957 & 260,752 & 68 & & 45 \\
\hline Indonesia & 94,432 & 52 & -20.3 & 3699 & 14,428 & 86,396 & 82 & & 40 \\
\hline Myanmar & 31,773 & 43 & -19.0 & 988 & 3380 & 39,180 & - & & 98 \\
\hline Asia & 592,512 & 19 & 2.8 & 104,596 & 201,000 & 548,000 & 87 & & 65 \\
\hline Finland & 22,157 & 73 & 1.2 & 5904 & 55,152 & 5933 & - & & 65 \\
\hline France & 15,954 & 29 & 9.7 & 1633 & 33,295 & 29,099 & 100 & & 43 \\
\hline Russia & 809,090 & 49 & 0.0 & 16,991 & 134,870 & 50,905 & 22 & & 100 \\
\hline Spain & 18,173 & 36 & 31.5 & 2680 & 15,827 & 1760 & 100 & & 19 \\
\hline Sweden & 28,203 & 69 & 3.4 & 3613 & 75,539 & 10,826 & - & & 100 \\
\hline Europe & $1,005,001$ & 45 & 1.6 & 58,904 & 568,000 & 167,000 & 32 & & 95 \\
\hline Guatemala & 3657 & 34 & -23.0 & 173 & 800 & 533 & - & & - \\
\hline Honduras & 5192 & 46 & -36.2 & 0 & 1001 & 9984 & - & & 21 \\
\hline Canada & 310,134 & 34 & 0.0 & 8963 & 214,057 & 3251 & 92 & & 8 \\
\hline Mexico & 64,802 & 33 & -7.8 & 3203 & 6055 & 688 & - & & 13 \\
\hline United States of America & 304,022 & 33 & 2.6 & 25,363 & 481,006 & 51,101 & 44 & & 68 \\
\hline North \& Central America & 705,393 & 33 & -0.4 & 25,977 & 706,000 & 77,000 & 68 & & 66 \\
\hline Australia & 149,300 & 19 & -3.4 & 1903 & 26,672 & - & 21 & & 21 \\
\hline New Zealand & 8269 & 31 & 7.1 & 1812 & 23,734 & - & 61 & & 84 \\
\hline Papua New Guinea & 28,726 & 63 & -8.9 & 86 & 2832 & - & n.s. & & 1 \\
\hline Oceania & 191,384 & 23 & -3.7 & - & 55,000 & 1000 & 19 & & 24 \\
\hline Bolivia & 57,196 & 53 & -8.9 & 20 & 871 & 38 & 68 & & 18 \\
\hline Brazil & 519,522 & 62 & -9.6 & 7418 & 117,048 & 122,573 & 47 & & 17 \\
\hline Colombia & 60,499 & 55 & -3.2 & 405 & 2106 & 11,225 & - & & - \\
\hline Paraguay & 17,582 & 44 & -2.0 & & & & & & \\
\hline Peru & 67,992 & 53 & -3.1 & 993 & 2051 & 7243 & 28 & & 90 \\
\hline Venezuela & 46,275 & 52 & -11.1 & - & 1321 & 6 & - & & - \\
\hline South America & 864,351 & 49 & -8.7 & 12,375 & 180,000 & 167,000 & 49 & & 16 \\
\hline World & $4,033,060$ & 31 & -3.2 & 218,022 & $1,783,000$ & 1,576,000 & 52 & & 52 \\
\hline
\end{tabular}

Sources: (FAO, 2010), Note: -, data not available; n.s., not significant. 
Table 4. Basic data on selected countries and regions.

\begin{tabular}{|c|c|c|c|c|c|c|c|c|c|c|}
\hline \multirow[b]{2}{*}{ Country/region } & \multirow[b]{2}{*}{$\begin{array}{l}\text { Land area } \\
\text { (1000 ha) }\end{array}$} & \multirow[b]{2}{*}{$\begin{array}{c}\text { Total } \\
\text { population } \\
(1000)\end{array}$} & \multicolumn{3}{|c|}{ Population 2008} & \multicolumn{2}{|c|}{ GDP 2008} & \multirow[b]{2}{*}{$\begin{array}{l}\text { Economic } \\
\text { freedom } \\
(0-100)\end{array}$} & \multirow[b]{2}{*}{$\begin{array}{c}\text { Property } \\
\text { rights } \\
(0-100)\end{array}$} & \multirow[b]{2}{*}{$\begin{array}{c}\text { Freedom } \\
\text { from } \\
\text { corruption } \\
(0-100)\end{array}$} \\
\hline & & & $\begin{array}{c}\text { Density } \\
\text { (population/ } \\
\mathbf{k m}^{2} \text { ) }\end{array}$ & $\begin{array}{l}\text { Annual } \\
\text { growth } \\
\text { rate } \\
(\%)\end{array}$ & $\begin{array}{c}\text { Rural } \\
\text { (\% of total) }\end{array}$ & $\begin{array}{c}\text { Per } \\
\text { capita } \\
\text { (PPP) } \\
\text { (US\$) }\end{array}$ & $\begin{array}{c}\text { Annual } \\
\text { growth } \\
\text { rate } \\
(\%)\end{array}$ & & & \\
\hline Angola & 124,670 & 18,021 & 14 & 2.7 & 43 & 5820 & 13.2 & 46 & 20 & 19 \\
\hline Congo DR & 226,705 & 64,257 & 28 & 2.8 & 66 & 314 & 6.2 & 41 & 10 & 19 \\
\hline Mozambique & 78,638 & 22,383 & 28 & 2.4 & 63 & 838 & 6.8 & 57 & 30 & 25 \\
\hline Tanzania & 88,580 & 42,484 & 48 & 2.9 & 75 & 1301 & 7.5 & 57 & 30 & 26 \\
\hline Zambia & 74,339 & 12,620 & 17 & 2.5 & 65 & 1357 & 6.0 & 60 & 30 & 30 \\
\hline Africa & $2,974,011$ & 987,280 & 33 & 2.3 & 61 & 2787 & 5.2 & - & - & - \\
\hline China & 942,530 & $1,344,919$ & 143 & 0.6 & 57 & 5971 & 9.0 & 52 & 20 & 36 \\
\hline Japan & 36,450 & 127,293 & 349 & -0.1 & 34 & 34,129 & -0.7 & 73 & 80 & 77 \\
\hline India & 297,319 & $1,181,412$ & 397 & 1.4 & 71 & 2946 & 6.1 & 55 & 50 & 34 \\
\hline Indonesia & 181,157 & 227,345 & 125 & 1.2 & 49 & 3994 & 6.1 & 56 & 30 & 28 \\
\hline Myanmare & 65,755 & 49,563 & 75 & 0.9 & 67 & 1200 & 4.0 & 37 & 5 & 14 \\
\hline Asia & $3,091,407$ & $4,075,307$ & 132 & 1.1 & 59 & 6095 & 2.9 & - & - & - \\
\hline Finland & 30,409 & 5304 & 17 & 0.4 & 37 & 36,195 & 0.9 & 74 & 90 & 89 \\
\hline France & 55,010 & 62,036 & 113 & 0.5 & 23 & 33,058 & 0.4 & 65 & 80 & 69 \\
\hline Russia & $1,638,139$ & 141,394 & 9 & -0.4 & 27 & 15,923 & 5.6 & 41 & 25 & 22 \\
\hline Spain & 49,919 & 44,486 & 89 & 1.0 & 23 & 31,674 & 1.2 & 70 & 44 & 41 \\
\hline Sweden & 41,033 & 9205 & 22 & 0.5 & 16 & 36,961 & -0.2 & 70 & 70 & 61 \\
\hline Europe & $2,214,726$ & 731,805 & 33 & 0.1 & 28 & 25,585 & 1.1 & - & - & - \\
\hline Guatemala & 10,843 & 13,686 & 126 & 2.5 & 52 & 4760 & 4.0 & 62 & 35 & 34 \\
\hline Honduras & 11,189 & 7319 & 65 & 2.0 & 52 & 3932 & 4.0 & 59 & 30 & 25 \\
\hline Canada & 909,351 & 33,259 & 4 & 1.0 & 20 & 39,078 & 0.4 & 81 & 90 & 87 \\
\hline Mexico & 194,395 & 108,555 & 56 & 1.0 & 23 & 14,570 & 1.8 & 68 & 50 & 33 \\
\hline $\begin{array}{l}\text { United States of } \\
\text { America }\end{array}$ & 916,193 & 311,666 & 34 & 1.0 & 18 & 46,350 & 0.4 & 78 & 85 & 75 \\
\hline $\begin{array}{l}\text { North \& Central } \\
\text { America }\end{array}$ & $2,134,979$ & 536,301 & 25 & 1.0 & 23 & 33,443 & 0.5 & - & - & - \\
\hline Australia & 768,228 & 21,074 & 3 & 1.1 & 11 & 38,784 & 3.7 & 83 & 95 & 94 \\
\hline New Zealand & 26,771 & 4230 & 16 & 0.9 & 14 & 27,260 & -1.1 & 82 & 95 & 94 \\
\hline $\begin{array}{l}\text { Papua New } \\
\text { Guinea }\end{array}$ & 45,286 & 6577 & 15 & 2.4 & 88 & 2180 & 6.6 & 53 & 20 & 21 \\
\hline Oceania & 849,094 & 34,940 & 4 & 1.3 & 30 & 27,630 & 3.2 & - & - & - \\
\hline Bolivia & 108,438 & 9694 & 9 & 1.8 & 34 & 4277 & 6.1 & 50 & 10 & 27 \\
\hline Brazil & 832,512 & 191,972 & 23 & 1.0 & 14 & 10,304 & 5.1 & 56 & 50 & 37 \\
\hline Colombia & 110,950 & 45,012 & 41 & 1.5 & 26 & 8797 & 2.5 & 68 & 50 & 37 \\
\hline Paraguay & 39,730 & 6238 & 16 & 1.8 & 40 & 4704 & 5.8 & & & \\
\hline Peru & 128,000 & 28,837 & 23 & 1.2 & 29 & 8509 & 9.8 & 69 & 40 & 37 \\
\hline Venezuela & 88,205 & 28,121 & 32 & 1.7 & 7 & 12,818 & 4.8 & 38 & 5 & 19 \\
\hline South America & $1,746,292$ & 384,892 & 22 & 1.2 & 17 & 10,446 & 5.4 & - & - & - \\
\hline World & $13,010,509$ & $6,750,525$ & 52 & 1.2 & 50 & 10,394 & 1.7 & 61 & 44 & 41 \\
\hline
\end{tabular}

Sources: (FAO, 2010; Heritage Foundation, 2011), Note: -, data not available; n.s., not significant. 
results represent statutory tenure only. A forest tenure assessment in 30 tropical countries (RRI \& ITTO, 2009) found that $18 \%$ of forest area owned by communities and indigenous people and another $4 \%$ was designated for their use. Community forest ownership is particularly notable in Mexico and Papua New Guinea.

\subsection{Trends in Global Forest Ownership}

FAO (2010) reports that from 1990 to 2005 the amount of public ownership of forests has declined slightly. While ownership shifts may be responsible for part of this change, deforestation is seen as the major cause of decline in the area of publicly owned forests. On the other hand, the level of private ownership has increased slightly, primarily through the establishment of forest plantations which represents one of a few avenues available for acquiring private forest ownership. Further, state management of public forests has declined over the past 15 years (FAO, 2010). This occurred, for example, in the Russian Federation. A shift towards community management of publicly owned forests also occurred in South America. Similar trends in forest area under various ownerships were observed in Asia and Africa to some extent, however, these trends were sometimes attributed to deforestation.

Property rights continue to change as government policies towards forests and markets evolve. If one were to classify recent forest tenure approaches and reforms, they would fall into the following categories: 1) privatization of forest rights; 2) contracts and concessions; and 3) community forestry (FAO, 2011).

Privatization of forests has become more common recently. These changes include forest restitution in Eastern Europe involving the transfer of formal forest titles (Siry, 2003). However, most countries in the former Soviet Union decided to retain public forest ownership while allocating long-term timber and other user rights to private and communal entities. Australian states also privatized or are considering privatization of user rights to their state plantations (FAO, 2011). Queensland, for example, retains land ownership, while private investors have harvest rights and sale rights to plantations regenerated after harvest.

Vietnam has attempted a widespread forest privatization of use rights but not outright ownership. About a quarter of its forest land is now in private hands, by providing private owners with legal land use rights for 50 years (FAO, 2011). Similarly, China has moved towards private forest tenure by devolving the management of collective forests to individuals and cooperatives, and even foreign investors and partnerships with Chinese companies. The private sector groups have land use rights, including the right to sell them, but land still remains publicly owned. Tenure changes also occur within a specific private ownership group. Major private forest ownership change occurred in the United States with land transfers of about 15 million ha from vertically integrated forest products companies (VIFPCs) to institutional Timberland Investment and Management Organizations (TIMOs) and Real Estate Investment Trusts (REITs) (Siry, Cubbage, Newman, \& Izlar, 2010).

Contracts and concessions refer to private timber harvesting contracts, which provide for access and use rights. The state remains the owner in these contracts, and generally provides short-term use rights to proprietors, claimants, or authorized users, per the schema noted in Table 1. These concessions are common in several tropical countries, such as Indonesia and Brazil, and in some developed countries, such as Canada. An early study by Repetto \& Gilles (1988) analyzed tropical harvesting concessions in several countries, pointing out market distortions, value destruction, and resource degradation. Modern concessions on national forests such as in Canada and Brazil appear more promising. Brazil has rigorous legal standards for safeguards for biological integrity of affected forest areas (Bauch, Sills, Rodriguez, McGinley, \& Cubbage, 2009; FAO, 2011), and Canada has rigorous laws and required forest certification of most federal and provincial lands as well (Lister, 2011).

Community forestry has received recently most attention. It is based on the involvement of local people in various capacities, usually allowing them some of access, use, enforcement, and management rights. The role of local communities in forest management has been expanding in South America, Africa, and Asia as governments devolve property rights to local people who live in the forests, and who are thought to have greater incentives to implement sustainable forest management. A shift towards community forestry implies various strategies transferring various property rights to local communities.

\subsection{Forest Resource Conditions, Management, Protection, and Sustainability}

An examination of world forest resource and management data (Table 3) indicates that problems associated with deforestation and degradation are largely confined to tropical and subtropical forest areas. Whether this stems from forest tenure, weak governance, rapid development and conversion to agriculture land, or other fac- 
tors is difficult to determine. But the status of forest conditions can provide insight into the contributions of forest tenure to sustainable forest management.

From 1990 to 2005 the largest forest losses occurred in Africa and South America. Asia noted a slight increase in forest area due to massive afforestation efforts in China and to some extent in India. However, forest losses in countries such as Indonesia and Myanmar were substantial (1990-2005: $-20.3 \%,-19.0 \%$, respectively). Rapid deforestation occurred in countries with relatively abundant, as measured by forest cover, forest resources.

We tested for correlations among deforestation rates and many of the forest, economic, and social variables. Of those three were significant. Having more public forests $(p=0.022)$ was correlated with more loss of forests, as was having more forest land $(p=0.093)$. Conversely, a positive correlation between having more planted forests and increased areas of forest land existed $(p=0.035)$. No other variables examined proved to have statistically significant correlations with deforestation rates. There was not significant correlation in the data series, so it seems that public and total forest land area are associated with deforestation, all other factors being constant. The increasing area of planted forests is probably more associated with afforestation in developed countries than overall increases in area per se, since the planted areas are quite small in total.

Forest area in temperate and boreal regions has been stable or increasing. That applies to Europe, Canada, and the United States. Of course, many of the developed countries harvested or otherwise removed much of their original forest resources a century or more ago as they developed, and have since managed a more sustainable use of current forest goods and services, abetted at least partially by imports from developing countries. In addition, forest area has increased as agricultural intensification succeeded greatly in developed countries, and as urban populations actually fostered more forest cover for amenity values, not for timber production.

The world's reported wood harvest is nearly equally divided between industrial roundwood and wood fuel. The regions with high deforestation rates are characterized by a very high proportion of wood fuel in total harvest. This indicates that, among other things, these forests are used primarily to meet subsistence needs of local people for cooking, heating, as well as for lumber for housing construction. It also suggests that wood markets, processing industries, and infrastructure may be poorly developed which may hinder forest-based generation of employment and income. It is only in North America, Europe, and Oceania where most wood harvested is processed into paper, paperboard, lumber and other products, although South America and China are increasing industrialization rapidly in the forest products sector.

The world has increased its reliance on intensively managed plantations to meet its growing wood needs. FAO (2010) reports the area of plantation of more than 218 million ha. Three-quarters of plantations have wood production as their major management objective. Most productive plantations are located in South America (Brazil, Chile), the United States, Australia and New Zealand, and Southern Europe. The largest area of forest plantations can be found in Asia, particularly in China, Japan, and also India. However, about $60 \%$ of the 77 million ha of Chinese plantations and all of Japan's 10 million ha are classified as being established for environmental protection purposes or are characterized by low productivity. Carle \& Holmgren (2008) estimated that planted forests produced 1.2 billion $\mathrm{m}^{3}$ of industrial roundwood in 2005, or about $66 \%$ of total industrial roundwood production of 1.8 billion $\mathrm{m}^{3}$.

A permanent forest estate is defined by FAO as forest as an area to be retained in forest uses in the foreseeable future. FAO (2010) indicates that for 122 reporting countries (accounting for 84\% of the world's forest area) roughly one-half of their total forest area is designated as permanent forest (Table 3). FAO estimates that the area of forests designated permanent has increased by at least 25 million ha since 1990. Still, another half of the world's forests lacks this designation, possibly indicating developmental pressures for at least some of these areas.

FAO (2010) reports that nearly $12 \%$ of the world's forests are set aside and managed primarily for biodiversity protection, which generally precludes timber harvest. While not the same as a protected forest area, the primary function of these forest areas is biodiversity conservation. All regions, except for Europe, have more than $10 \%$ of forest land set aside for this very purpose. This area has increased by 35\% from 1990 to 2010 . Forests in protected areas, legally designated as national parks, wilderness areas, wildlife reserves, and other protected areas amount to nearly $13 \%$ of the world's forests. Asia has the highest share of protected forest area with nearly $24 \%$ of its forests with protected status.

It is further estimated (FAO, 2010) that at least 1.6 billion ha of forests are covered by a management plan, which indicates that at least at a minimum level, some forest resources have been inventoried and some deci- 
sions regarding their use and conservation have been made. FAO (2010) also attempted to assemble information about the area of forests managed sustainably, where they must fulfill one the following conditions: 1) independently certified; 2) existence of long-term forest management plans with information available about their content and quality; 3) under community-based management with secure tenure and high quality management; and 4) within protected areas, well managed, and with secure boundaries. Despite numerous data problems, it appears that most of the forests in Europe and less than a half of the forests in Asia and North and Central America can be considered as sustainably managed. Only a small fraction of forests in Africa and South America may be considered sustainably managed, given the above criteria. However, problems persist in North America as well, where development lags or other pressures exist. Russia has not lost much forest area, but its exploitation of its forests to large extent resembles resource mining rather than planned sustainable management of forests. And even natural disasters, such as the massive pine beetle outbreaks in Canada, may threaten otherwise stable forest ecosystems and communities.

Overall, FAO (2010) noted that over the past two decades the global forest situation has remained relatively stable. While deforestation has continued in some regions, its pace has slowed down recently. Noted positive developments include growth in forest areas set aside for conservation and protection purposes, plantation area growth, and some ownership changes. However, some of these efforts still need to be fully implemented.

\subsection{Economic Development, Property Rights, and Corruption}

We also summarized data on the economic conditions, economic freedom, property rights, and corruption as proxies for assessing the strengths of tenure rights and sustainable forestry in the countries analyzed (Table 4), based on Heritage Foundation (2011) ratings. Many countries experiencing widespread forest degradation had low ratings for each criterion. This included property rights score of about 30 or lower. These scores indicate that property rights are weakly protected and administration is inefficient and possibly corrupt, property rights are difficult to enforce, and expropriation is not only possible but even common (Heritage Foundation, 2011).

Other factors may explain the low Heritage Foundation scores for many countries as well. The thesis that environmental degradation is correlated with economic development has been well accepted, and is exemplified by the Kuznet's Curve. This curve tracks increasing resource degradation at low levels of GDP per capita up to certain levels and then decreasing amounts of environmental degradation as per capita GDP increases (Grossman \& Kruger, 1995). The actual level of GDP where the rate of degradation levels out and then decrease is moot, and varies by sector, but Kauppi, Ausubel, Fang, Mather, Sedjo, \& Waggoner (2006) found that at about the \$4600 per capita annual income level, forest degradation seemed to start decreasing. Earlier, Rudel (1998) termed this a forest transition, evolving from deforestation and reforestation associated with development. This criterion would suggest that developed countries would be less likely to have much forest loss, and this seems to track the forest loss/GDP relations shown well, except for the case of Brazil and Angola. This factor of GDP per capita versus deforestation was not statistically significant in our sample, but other researchers found that it was with a larger set of countries.

The data on economic freedom, property rights, and freedom from corruption also could be associated with forest loss and tenure rights. Less developed countries generally fared worse in these respects as well. The amount of economic freedom in most developing countries was close to the world average, with the notable exceptions of Myanmar, Russia, and Venezuela. Australia, New Zealand, and Canada actually had the highest ratings for these categories. Large public ownership was somewhat more likely to be linked to poor rating for economic freedom, property rights, and freedom from corruption. But this may be more due to the fact that these African and Asian and more socialist countries were less developed, and owned all the land publicly. Mexico had almost all its land in community ownership, which could be considered a subset of public lands, but still rated moderately well. Canada, with 92\% public lands, was rated in the top three in each criterion.

\section{Forest Tenure and Sustainable Forest Management}

Directly judging global progress towards the achievement of sustainable forest management is difficult because basic variables such as forest area or stocking are probably derived from remotely sensed imagery, which itself has a level of validation uncertainty. In addition, the FAO (2010) forest sustainability assessment relies on regional and national information about the area of protected forests, forests with management plans, forests sustainably managed, as well as few other variables. While useful, this approach to understanding world-wide for- 
est trends has limitations. For example, many of these variables describe little about what occurs in practice. Understanding the area of forests with management plans means little unless their content and achievements are known. Likewise, the area of protected forests means little unless the real effectiveness of protection measures is known.

Assessing the links between forest tenure arrangements and forest management sustainability is even more difficult. It is apparent, however, that the extent of forest management plans, protection, or biodiversity conservation applies mostly to publicly owned forests in countries with large forest resources such as the Russian Federation, Canada, or Brazil. Deforestation and forest degradation are prevalent in several developing countries in the tropics, where forests are primarily under public ownership, and countries are developing rapidly and changing forests into agricultural or other landuses. Conversely, forest area is stable in the wholly public forests of Russia, where development pressures hardly exist. Following are a few examples of differing tenure arrangements and their outcomes.

\subsection{Example Tenure Regimes by Country}

The United States is unique among countries with large forest endowments because of the dominant position of privately owned forests (56\% of the total forest area), particularly in the southern part of the country. Private noncorporate owners, including individuals, Native American Tribes, unincorporated partnerships, clubs and lands leased by corporate interests, control 38\% of all forest land. Corporate owners encompassing legally incorporated entities, account for another $18 \%$ of all forest land. Private forests account for $92 \%$ of the wood harvested in the country (Smith, Miles, Perry, \& Pugh, 2009). While a substantial portion of harvest comes from intensively managed plantations, harvest from naturally regenerated forests dominates the mix. At the same time, much forest land is held for purposes other than wood production and is managed for the provision of non-wood forest outputs.

Most small owners in the U.S. do not have a formal or informal management plan (Butler, 2008) unless it is necessary due to involvement in a state or federal assistance program or an industry-led landowner assistance program. The level of forest management regulation is minimal in most states, with respect to both forest resource use and protection, and only few states have formal forest practices laws. Legal protection of private property rights is very strong. In conclusion, private forest ownership in the United States is characterized by some of the most comprehensive bundles of property rights (access, use, management, exclusion, and transfer) that can be found in any country. At the same time, forests in the United States have been managed sustainably (for wood production) for several decades now as indicated by stable or increasing forest area, and a rate of growth that exceeds harvest levels in all regions. Increasing U.S. forest area sustainability could be credited to the structure of property rights, or to the relatively stable domestic demand, increasing plantation intensification, and reliance on imports from other countries.

Similarly in Europe (excluding the Russian Federation) much of forest land is in private ownership, which consist of individuals, families, forest industries, and other private organizations such as corporations, cooperatives, religious and educational institutions, investment funds, and nature conservations societies (Schmithüsen \& Hirsch, 2010). The level of private forest ownership differs by region and country, but overall it has been growing. Little information is available about the existence of management plans, probably indicating that they are not very widespread among small owners. As in the United States, most holdings are small, which makes forest management challenging. Forest owner associations, particularly well developed in Scandinavian countries, help to address problems related to the economy of scale of small forest tracts management. Interestingly enough, harvest levels appear to be higher on public land than on private forest holdings and, not surprisingly, growth rates exceed harvest levels in private forests.

European private owners have a multitude of objectives for their forests, ranging from wood production to conservation, protection, recreation, and other services. The actual forest policy challenge is to increase harvests in private forests sustainably in an effort to meet aggressive European Union's renewable energy targets. Private forest owners, however, have a more limited bundle of property rights compared to private landowners in the United States. Private landowners in Europe still generally enjoy access, use, management, some exclusion, and transfer rights, and tenure is secure and permanent. However, broader public interests often allow public access to private forests and a range of non-wood uses. For example, in Finland recreational use of forests is free given the Everyman's Right (right of public access), provided that these activities do not cause damage, and activities 
such as camping and extraction of some non-timber forest products can be conducted on private land (Parviainen, Västilä, \& Suominen, 2010). Overall, forest management tends to be much more regulated in Europe and management discretion is more limited. Similar conclusions can be drawn for Japan and South Korea.

Due to the frequent lack of information, assessing the sustainability of community forestry is difficult. In many cases where people live in or near public forests they have developed arrangements regarding access and use of these resources. This indicates that community forestry, whether formally recognized or not, may be widespread in countries with traditions or laws allowing the use of public or private land by those who live nearby. There are numerous examples of sustainable managed community forests in Europe and North America, such as the Weaverville Community Forest in northern California (USA), where about 5260 ha of public forest lands are managed cooperatively by the community and federal agencies under a short-term agreement. Mexican political agrarian units (ejidos and comunidades agrarias) hold about $80 \%$ of the country's forest land and manage it sustainably (Klooster \& Masera, 2000). While there are usually many reasons behind forest resource degradation, at times shifts away from community rights may have triggered forest degradation (Grafton, 2000; Katila, 2008).

Characterizing property right bundles for communal forests is a difficult challenge, yet usually these rights include access, some withdrawal, management, and exclusion privileges. Occasionally, these arrangements may also include the right to sell the land. Tenure security and durability also vary greatly in community forests. For example, in Mexico's ejidos communities own the land and manage forests independently for timber and non-timber products. In other cases, communities may be tasked with and rewarded for assistance in protecting and managing state owned forests (FAO, 2011). Interestingly, Nepal allows permanent user rights to communities that are able to practice forestry (Gautam \& Shivakot, 2008).

\subsection{Outcomes of Forest Tenure Reforms}

Recent tenure reforms have generally improved forest conditions and production. Sustainable forest management did not have to be an objective of the reforms. Successful examples include community forestry programs in Nepal and Tanzania (FAO, 2011; Gautam \& Shivakot, 2008). However, forest tenure reforms do not necessarily lead to improved forest conditions, as could be the case in India. In Romania forest restitution resulted in some illegal harvests. Further, privatization of state forests in China and Vietnam, while viewed as somewhat successful in terms of resource conditions, has led to inequities and impoverishment of some people who are left behind in the process.

Attempted forest tenure reforms vary greatly in the context of bundle of rights as well as tenure security and duration. The results from six countries in Asia and Africa indicate that tenure reforms were often meant to transfer limited user rights to local levels, while the state retained control over forests (Katila, 2008), yet the transfer of management rights to local levels was rather limited. As a result, local participants had only a limited role in making management and harvesting decisions. Rights related to exclusion and resource use and management monitoring were transferred to local levels to a greater degree. The transfer of rights was also conditioned on fulfilling many requirements, such as developing detailed inventories or management plans. In allocating forest rights, subsistence uses were favored over commercial uses, limiting income generation potential.

Perhaps not so surprisingly, it has been common for a government to transfer mostly degraded forests or low productivity bare land to communities and individuals (FAO, 2011; Katila, 2008). Lastly, tenure security and duration were often limited in these cases. So it is in the context of this rather limited transfer of rights to forests, and the conditions of these forests, that forest tenure reforms are considered somewhat successful in terms of improving forest management practices and forest conditions.

\section{Discussion}

Forests are managed by governments, communities, private and public organizations, and individuals. Their economic, ecological, and social performance varies, as numerous examples of successes and failures for each group demonstrate. However, the main concern here is the sustainability of global forest resources. This appears to apply mainly to tropical and subtropical regions and countries.

Forests in developing tropical countries are predominantly publicly owned, and these countries are relatively poor, as measured by GDP per capita (Table 4). However, they may be developing fast, as measured by GDP growth, which actually may put additional pressures on forest resources leading to unsustainable resource ex- 
ploitation or land conversion to non-forest uses, at least in the short run, per the Kuznet's curve concept. In many of these countries, property rights are not well protected and corruption is common. To date, central government public ownership has not stopped forest loss, although some of this may be exploitation or conversion to agriculture or grazing to foster economic development, as occurred with developed countries centuries ago.

One policy alternative is to reform forest tenure and transfer forest rights to communities and individuals (Stroup, 1998), and possibly some other public or private organizations. However, private ownership alone does not prevent forest loss, as evidenced by rates of forest land loss in Papua New Guinea, Guatemala, and Paraguay. Similarly, community ownership has been relatively stable in Mexico for almost a century, but the country has still had high deforestation rates in recent decades. In addition, Brazil has decreased loss of public forest lands in the Amazon significantly in the last few years after passage of its new forest law, as well as due to the moderate economic recession.

Since Hardin's (1968) “Tragedy of the Commons” much research has been accomplished to clarify the resulting confusion surrounding the commons. Theoretical, experimental, and applied research has indicated that decentralized systems, involving community forestry, can perform as well as centralized systems in the management of common-pool resources such as forests (Ostrom, 2010). Community management has been shown to be effective, resilient, and adaptable, in some cases, over the course of centuries. Both communal and individual owners, although not without their own problems, have amply demonstrated their ability to manage forests sustainably, particularly if certain conditions are met. Our focus on community forest management is important because it is the most prevalent type of tenure reform considered in terms of forest area affected.

One question from this discussion concerns the design of successful tenure reforms, and how to achieve this. Frequent problems currently experienced include insufficient devolution of forest rights, the allowance of only limited use and management rights, and the failure to create strong incentives to manage the resource. Tenure security and duration are also questionable to say the least. The transfer of rights often depends on additional requirements such as the development of inventories or management plans as well as other conditions. These conditions may be difficult to meet by poor people or communities with limited resources. New owners often receive rights to low value bare land and forests, which further hampers their chances of success.

It appears that the devolution of forest rights should be farther reaching, including at least stronger use and management rights, to ensure that tenure is secure and durable, given the long-term nature of forest production (FAO, 2011; Katila, 2008). Overly detailed regulations and rules for new owners should rather be avoided. And, if it is a government's intention to lift poor people out of poverty, one might argue that these people should be given something of value.

Furthermore, much work has been accomplished in developing an Institutional Analysis and Development (IAD) framework to analyze diverse institutional settings and complex interactions of individuals within markets, firms, families, communities, legislature and government, including applications to forest resources (Ostrom, 2010). The framework has been used to analyze multiple cases and identify rules that resulted in the development of successful solutions by organized resource users. Most of the tenure and policy design principles posited by Ostrom (2010) and Cox, Arnold, \& Villamayor (2010) should apply to all types of tenure reforms and forest owners. So the question or the challenge really, is how to meet these conditions in countries with incomplete regulatory frameworks and very poor governance.

As countries evolve and develop, the quality of regulatory frameworks and governance will improve as well, and perhaps pressure for development and conversion to other uses will decrease, making the implementation of forest tenure reforms easier. Why that may well be the case, the question is how much forest will have been left by that time? It appears that local users, whether communities or individuals, currently have an advantage because of their attachment to the land. Their continuous presence in the area helps monitor local forest resources, and since they are among the first to gain or lose, given sufficient incentives, they also may invest in sustained management. At the same time, local people would often be the ones with fewest resources available to implement forest management. In all likelihood, some customary tenure arrangements are already in place, and tenure reforms should consider them as a starting point. Still, even customary tenure may be inequitable or discriminatory.

Some of the challenges and requirements posed here can be addressed, likely with international help, by relying on lessons already learned and available technologies. For example, GIS and remote sensing technologies may help in assessing and monitoring resources, developing management plans, or land titling. Rather than relying on advanced and possibly more difficult to implement locally management approaches, which may require 
detailed inventories, one may rely on the long-known forest area regulation approaches (rather than volume regulation approaches) which may provide sufficient environmental safeguards.

Capacity building will be necessary for both government agencies and local forest users and international aid programs may certainly help in this regard. If a government feels that it will be able to meet some of its political objectives through forest tenure reform, it may be more likely to try such changes. There also is a promise, although still somewhat vague, of potentially large payments for ecosystem services through programs such as REDD+ that would benefit both central governments and local people. Rules developed under such programs may require that certain tenure reforms take place.

In addition, a few words of caution are due. Forest tenure reforms are complex and the outcomes are somewhat unpredictable. There will be failures, and major reassignments of rights to valuable resources will trigger conflict among underrepresented people and entrenched interests who have held power and tenure rights for decades or centuries. Further, land tenure did not evolve for the purpose of achieving sustainable management. Forest tenure reforms may help to achieve it but do not guarantee it. Many forest tenure reforms have had objectives other than achievement of sustainable forest management.

Sustainable forest management practiced in many temperate and boreal forests may result from many factors other than particular forest tenure arrangements. This may be the case because the remaining forests are more valuable than other land uses as is evident in North America or Europe (Mendelsohn, 1994). Furthermore, many countries with relatively abundant forest resources but facing demographic pressures may need land for agriculture and development purposes and consequently deforestation may constitute an efficient economic activity from a social point of view. While we tend to view all deforestation as a wasteful activity, from other points of view this may not be the case.

Forest tenure reforms to retain land in forests and manage it sustainably offer opportunities to improve forest management at least in some cases. Developing countries face substantial problems in achieving these objectives, due to problems in both the public and private sectors. Public land ownership has not been particularly successful, although private land failures can be as significant in the few cases where private land predominates in the tropics. Thus reforms of public land management or incentives for better private land management are needed.

Central governments may be reluctant to relinquish public land or regulatory power, and lack funds to provide extensive incentives to private land holders. The challenge is to balance these proclivities with the ability to foster public, communal, or individual sustainable forest management. Thus gradual approaches can be tried, and if successful, they would lead to bolder changes. However bolder reforms may have a better chance of success. The lessons that can be gathered here are probably counterintuitive from a government point of view but worth considering nonetheless: 1) give stronger and more secure property rights to forests; 2) include productive forest areas in tenure reforms; 3 ) make tenure reform requirements as simple as possible and consider voiding some of them altogether; and 4) allow sufficient time and resources for reforms to be implemented.

\section{Conclusions}

This review examined the principles and key literature related to forest tenure and sustainable forest management, and then examined the status of sustainable forestry and land ownership at the aggregate national level for major forested countries. The classification of bundles of rights in land suggests that clearly defined and assigned rights are apt to enhance sustainability. The design principles summarized by Ostrom (2010) and Cox, Arnold, \& Villamayor (2010) suggest guidelines that will foster sustainable natural resource management.

The forestry literature largely confirms these principles. Whatever form a forest management institution takes (public, private, communal), to be effective it must have clear and legitimate rules regarding who has access and use rights to forests; monitoring and enforcement mechanisms with sufficient resources; and sanctions for rule breaking. Involvement of local forest users in developing rules, and their acceptance of those rules makes them more likely to follow them and to participate in monitoring and enforcement. Furthermore, when institutions fit the local context and are adaptive to social, economic, and environmental change processes, they are more robust and enduring.

The analyses of countries as a whole suggest that problems of forest land loss and sustainable forest management are related to the amount of public land and the difference between developed and developing countries. Larger areas of public land appear to be hard to maintain in forests, either through mere logistical problems or due to outright governance and tenure problems. Developed countries have largely achieved a stable level of land use and resource extraction after centuries of exploitation of forests and natural resources. Developing 
countries are still proceeding along the Kuznet's curve, and exploiting and deforesting in order to achieve higher levels of economic well being. Many developed countries do have greater amounts of private forest land than developing countries, which have occurred as the countries’ progress. It may be that similar forest ownership transfers in developing countries could parallel the economic development of the northern hemisphere. But private or communal ownership is not the only answer, and indeed has often not succeeded at fostering sustainable forest management in poor countries. Other socioeconomic factors we examined were not significantly associated with deforestation, at least with the data set available. As Geist \& Lambin (2002) noted, it is rather difficult to establish a universal link between the extent of deforestation and its potential causes.

The institutional design principles suggested by Ostrom (2010) and others make sense, and should be applied to public, communal, and private lands. Boundaries for users, nonusers, and natural resource rights holder should be clear; rights should conform to local traditions; benefits and costs of use should be fair; resource users should participate in allocation decisions; and they should be involved in monitoring. Implementation of tenure rights also needs to make sense: sanctions for violating rules should start small but become stronger; local, inexpensive, and fast mechanisms should be used to resolve conflicts; governments should recognize the rights of local users to make their own rules; and systems should link local common-pool rights to higher government systems. Public, communal, or private land tenure systems can achieve these rights. As suggested, which method will be best will depend on the social context, the nature of the resource assets, the stage of economic development, and the status and power of rights holders in the land and of the government.

\section{References}

Alchian, A., \& Demsetz, H. (1973). The Property Rights Paradigm. The Journal of Economic History, 33, 16-27. http://dx.doi.org/10.1017/S0022050700076403

Andersson, K., \& Gibson, C. (2007). Decentralized Governance and Environmental Change: Local Institutional Moderation of Deforestation in Bolivia. Journal of Policy Analysis and Management, 26, 99-123. http://dx.doi.org/10.1002/pam.20229

Bauch, S., Sills, E., Rodriguez, L. C. E., McGinley, K., \& Cubbage, F. W. (2009). Forest Policy Reform in Brazil. Journal of Forestry, 107, 132-138.

Bocco, G., Rosete, F., Bettinger, P., \& Velázquez, A. (2001). Developing a GIS Program in Rural Mexico. Journal of Forestry, 99, 14-19.

Bromley, D. (1991). Environment and Economy: Property Rights and Public Policy. Cambridge, UK: Blackwell.

Bruce, J. W. (1998). Review of Tenure Terminology. Tenure Brief, 1, 8.

Butler, B. (2008). Family Forest Owners of the United States, 2006. USDA Forest Service.

Canadell, J. G., \& Raupach, M. R. (2008). Managing Forests for Climate Change Mitigation. Science, 320, 1456-1457. http://dx.doi.org/10.1126/science.1155458

Carle, J., \& Holmgren, P. (2008). Wood from Planted Forests: A Global Outlook 2005-2030. Forest Products Journal, 58, 6-18.

Cashore, B., Galloway, G., Cubbage, F., Humphreys, D., Katila, P., Levin, K., Maryudi, A. et al. (2010). Ability of Institutions to Address New Challenges. In G. Merry, P. Katila, G. Gallowey, R. I. Alfaro, M. Kanninen, M. Lobovikow, \& J. Varjo (Eds.), Forests and Society—Responding to Global Drivers of Change (IUFRO World Series 2010, Vol. 25, pp. 441-486). Vienna: IUFRO.

Charnley, S., \& Poe, M. R. (2007). Community Forestry in Theory and Practice: Where Are We Now? Annual Review of Anthropology, 36, 301-336. http://dx.doi.org/10.1146/annurev.anthro.35.081705.123143

Coleman, E. A. (2009). Institutional Factors Affecting Biophysical Outcomes in Forest Management. Journal of Policy Analysis and Management, 28, 122-146. http://dx.doi.org/10.1002/pam.20405

Coleman, E. A., \& Steed, B. C. (2009). Monitoring and Sanctioning in the Commons: An Application to Forestry. Ecological Economics, 68, 2106-2113. http://dx.doi.org/10.1016/j.ecolecon.2009.02.006

Cox, M., Arnold, G., \& Villamayor, S. (2010). A Review of Design Principles for Community-Based Natural Resource Management. Ecology and Society, 15, 4-38.

Dietz, T., Ostrom, E., \& Stern, P. C. (2003). The Struggle to Govern the Commons. Science, 302, 1907-1912. http://dx.doi.org/10.1126/science.1091015

Food and Agriculture Organization of the United Nations (FAO) (2002). Land Tenure and Rural Development, FAO Land Tenure Studies. Rome: Food and Agriculture Organization of the United Nations.

Food and Agriculture Organization of the United Nations (FAO) (2010). Global Forest Resources Assessment 2010, FAO 
Forestry Paper 163. Rome: Food and Agriculture Organization of the United Nations.

Food and Agriculture Organization of the United Nations (FAO) (2011). Reforming Forest Tenure: Issues, Principles and Process, FAO Forestry Paper 165. Rome: Food and Agriculture Organization of the United Nations.

Gautam, A., \& Shivakot, G. (2008). Evolution, Impacts, and Challenges of Community-Based Forestry in Nepal. In E. L. Web, \& G. P. Shivakot (Eds.), Decentralization, Forests, and Rural Communities. New Delhi: Sage Publications.

Geist, H. J., \& Lambin, E. F. (2002). Proximate Causes and Underlying Forces of Tropical Deforestation. BioScience, 52, 143-150. http://dx.doi.org/10.1641/0006-3568(2002)052[0143:PCAUDF]2.0.CO;2

Godoy, R., Jacobson, M., De Castro, J., Aliaga, V., Romero, J., \& Davis, A. (1998). The Role of Tenure Security and Private Time Preference in Neotropical Deforestation. Land Economics, 74, 162-170. http://dx.doi.org/10.2307/3147048

Grafton, R. Q. (2000). Governance of the Commons: A Role for the State? Land Economics, 76, 504-517. http://dx.doi.org/10.2307/3146949

Grossman, G., \& Kruger, A. (1995). Economic Growth and the Environment. Quarterly Journal of Economics, 110, $353-377$. http://dx.doi.org/10.2307/2118443

Hardin, G. (1968). Tragedy of the Commons. Science, 162, 1243-1248. http://dx.doi.org/10.1126/science.162.3859.1243

Heritage Foundation (2011). 2011 Index of Economic Freedom. Washington DC: Heritage Foundation.

Karsenty, A., Drigo, I., Piketty, M., \& Singer, B. (2008). Regulating Industrial Forest Concessions in Central Africa and South America. Forest Ecology and Management, 256, 1498-1508. http://dx.doi.org/10.1016/j.foreco.2008.07.001

Katila, P. (2008). Devolution of Forest-Related Rights: Comparative Analysis of Six Developing Countries, Tropical Forestry Reports 33. Helsinki: University of Helsinki, Vikki Tropical Resources Institute.

Kauppi, P. E., Ausubel, J. H., Fang, J., Mather, A. S., Sedjo, R. A., \& Waggoner, P. E. (2006). Returning Forests Analyzed with the Forest Identity. Proceedings of the National Academy of Sciences of the United States of America, 103, 1757417579. http://dx.doi.org/10.1073/pnas.0608343103

Klooster, D., \& Masera, O. (2000). Community Forest Management in Mexico: Carbon Mitigation and Biodiversity Conservation through Rural Development. Global Environmental Change, 10, 259-272. http://dx.doi.org/10.1016/S0959-3780(00)00033-9

Larson, A. M., Cronkleton, P., Barry, D., \& Pacheco, P. (2008). Tenure Rights and Beyond: Community Access to Forest Resources in Latin America. Bogor: Center for International Forestry Research (CIFOR).

Lister, J. (2011). Corporate Social Responsibility and the State: International Approaches to Forest Co-Regulation. Vancouver: UBC Press.

Lynch, O. (2011a). Wither the People? Demographic, Tenurial and Agricultural Aspects of the Tropical Forestry Action Plan. Washington DC: World Resources Institute.

Lynch, O. (2011b). Mandating Recognition: International Law and Native/Aboriginal Title. Washington DC: The Rights and Resources Initiative.

Mendelsohn, R. (1994). Property Rights and Tropical Deforestation. Oxford Economic Papers, New Series, 46, 750-756.

Ostrom, E. (1990) Governing the Commons: The Evolution of Institutions for Collective Action. Cambridge: Cambridge University Press. http://dx.doi.org/10.1017/CBO9780511807763

Ostrom, E. (2000). Private and Common Property Rights. In B. Boudewijn, \& G. De Geest (Eds.), Encyclopedia of Law and Economics, Vol. II. Civil Law and Economic. Cheltenham: Edward Elgar.

Ostrom, E. (2005). Understanding Institutional Diversity. Princeton, NJ: Princeton University Press.

Ostrom, E. (2010). Beyond Markets and States: Polycentric Governance of Complex Economic Systems. American Economic Review, 100, 641-672. http://dx.doi.org/10.1257/aer.100.3.641

Ostrom, E., \& Hess, C. (2007). Private and Common Property Rights. Bloomington, IN: Social Science Electronic Publishing Inc.

Pacheco, P., Barry, D., Cronkleton, P., \& Larson, A.M. (2008). The Role of Informal Institutions in the Use of Forest Resources in Latin America, Forests and Governance Program Paper 15. Bogor: CIFOR.

Parviainen, J., Västilä, S., \& Suominen, S. (2010). Finnish Forests and Forest Management. In Finland's Forests in Changing Climate, Working Papers of the Finnish Forest Research Institute, No. 159. Vantaa: Finnish Forest Research Institute.

Repetto, R., \& Gilles, M. (1998). Public Policies and the Misuse of Forest Resources. Cambridge: Cambridge University Press.

RRI, \& ITTO (2009). Tropical Forest Tenure Assessment: Trends, Challenges and Opportunities. Washington DC: Rights and Resources Initiative.

Rudel, T. K. (1998). Is There a Forest Transition? Deforestation, Reforestation, and Development. Rural Sociology, 63, 533552. http://dx.doi.org/10.1111/j.1549-0831.1998.tb00691.x 
Schlager, E., \& Ostrom, E. (1992). Property-Rights Regimes and Natural Resources: A Conceptual Analysis. Land Economics, 68, 249-262. http://dx.doi.org/10.2307/3146375

Schmithüsen, F., \& Hirsch, F. (2010). Private Forest Ownership in Europe, Geneva Timber and Forest Study Paper 26. Geneva: United Nations Economic Commission for Europe/Food and Agriculture Organization of the United Nations.

Siry, J. (2003). Today and Tomorrow of Private Forestry in Central and Eastern Europe. In L. Teeter, B. Cashore, \& D. Zhang (Eds.), Forest Policy for Private Forestry: Global and Regional Challenges (pp. 81-93). Wallingford: CABI Publishing. http://dx.doi.org/10.1079/9780851995991.0081

Siry, J., Cubbage, F., Newman, D., \& Izlar, B. (2010). Forest Ownership and Management Outcomes in the U.S., in Global Context. International Forestry Review, 12, 38-48. http://dx.doi.org/10.1505/ifor.12.1.38

Smith, W. B., Miles, P. D., Perry, C. H., \& Pugh, S. A. (2009). Forest Resources of the United States, 2007, General Technical Report WO-78. Washington DC: USDA Forest Service, Washington Office.

Stroup, R. (1998). Privatizing Public Lands: Market Solutions to Economic and Environmental Problems. The Public Land \& Resources Law Review, 19, 79-101.

Stroup, R., \& J. Baden. (1973). Externality, Property Rights, and the Management of Our National Forests. Journal of Law and Economics, 16, 303-312. http://dx.doi.org/10.1086/466768

Sunderlin, W., Hatchers, J. \& Liddle, M. (2008). From Exclusion to Ownership? Challenges and Opportunities in Advanced Forest Tenure Reforms. Washington DC: Rights and Resources Initiative.

Tacconi, L. (2007). Decentralization, Forests and Livelihoods: Theory and Narrative. Global Environmental Change, 17, 338-348. http://dx.doi.org/10.1016/j.gloenvcha.2007.01.002

Terborgh, J., \& Peres, C. A. (2002). Indigenous People and Protected Areas. In J. Terborgh, R. van Schaik, \& L. Davenport (Eds.), Making Parks Work, Strategies for Preserving Tropical Nature. Washington DC: Island Press.

Tucker, C. M. (2010). Learning on Governance in Forest Ecosystems: Lessons from Recent Research. International Journal of the Commons, 4, 687-706.

White, A., \& Martin, A. (2002). Who Owns the World's Forests? Forest Tenure and Public Forests in Transition. Washington DC: Forest Trends. 